\title{
Konsep Dasar Ekonomi Dan Transaksi Dalam Muamalah Islam
}

Asaruddin Akbar' ${ }^{1}$, Muhammad Dahri², Muhammad Arsyam³

\footnotetext{
${ }^{1}$ Sekolah Tinggi Agama Islam (STAI) Darul Dakwah Wal-Irsyad (DDI) Kota Makassar, Indonesia Email: asarudinakbar@gmail.com

${ }^{2}$ Sekolah Tinggi Agama Islam (STAI) Darul Dakwah Wal-Irsyad (DDI) Kota Makassar, Indonesia Email: dahrii.kk@gmail.com

${ }^{3}$ Sekolah Tinggi Agama Islam (STAI) Darul Dakwah Wal-Irsyad (DDI) Kota Makassar, Indonesia

Email: arsyam0505@gmail.com
}

\section{Abstrak}

Pada dasarnya Islam merupakan agama yang sempurna, yang mengatur hal yang berkaitan dengan ekonomi. Sistem ekonomi islam adalah sebuah system yang tidak lahir dari hasil akal manusia, akan tetapi sebuah sistem yang berdasarkan ajaran islam yang bersumber dari alqur'an dan Hadits yang dikembangkan oleh pemikiran manusia yang memenuhi syarat dan ahli dalam bidangnya. Penerapan konsep ekonomi tentu terdapat transaksi yang telah dijelaskan dan diamalkan dalam kehidupan muslim, dalam hal ini dibahas pengertian para ahli, konsep dasar ekonomi islam, dan pembahasan mengenai transaksi dalam muamalah islam.

\section{Kata Kunci: Ekonomi, Transaksi, Muamalah Islam.}

\section{PENDAHULUAN}

Ekonomi islam di bangun untuk tujuan suci di tuntun oleh ajaran islam dan dicapai dengan cara-cara yang di tuntunkan pula oleh ajaran islam. Oleh karena itu, ke semua hal tersebut saling terkait dan terstruktur secara hierarkis, dalam arti bahwa spirit ekonomi islam tercermin dari tujuannya, dan di topang oleh pilarnya. Tujuan untuk mencapai falah hanya bisa (Islamic values),dan pilar operasional, yang tercermin dalam prinsip-prinsip ekonomi (Islam principles). Dari sinilah akan tampak suatu bangunan ekonomi islam dalam suatu paradigma, baik paradigma dalam berpikir dan berperilaku maupun bentuk perekonomiannya. Pilar ekonomi islam adalah moral.

Hanya dengan moral islam inilah bangunan ekonomi islam dapat tegak. Moralitas islam berdiri di atas suatu postulat keimanan dan postulat ibadah. Esensi dan moral islam adalah tauhid. Implikasi dari tauhid, bahwa ekonomi islam memiliki sifat transcendental ( bukan sekuler), di mana peranan Allah dalam seluruh aspek ekonomi menjadi mutlak. Ketika menjalankan ekonomi Islam seseorang haruslah berjalan sesuai dengan rambu-rambu yang telah ditetapkan oleh syariat, melalui syariatnya. kaidah yang berlaku untuk segala aktivitas ekonomi yaitu:

$$
\text { الأصل في لأشياء الإباحة إلا أن بذل دليل على تحريمها }
$$

"segala sesuatu (dalam hal muamalat) boleh dilakukan, sampai ada dalil yang mengharamkan."

Atas dasar kaidah di atas, maka segala aktivitas dalam ekonomi Islam yang membawa kemaslahatan dan tidak ada larangan di dalamnya Yaitu boleh dilakukan. 


\section{PEMBAHASAN}

\section{A. Konsep Dasar Ekonomi Islam}

\section{1) Pengertian Ekonomi Islam}

Kata ekonomi berasal dari kata Yunani, yaitu oikos berarti Rumah tanggah dan no-mos memiliki arti mengatur. maka ekonomi diartikan sebagai aturan Rumah tangga, atau manajemen Rumah tangga. Jadi Jadi ekonomi berarti aturan-aturan untuk Menyelenggarakan kebutuhan hidup manusia dalam rumah tangga, baik dalam rumah tangga rakyat(volkshuishouding) Maupun dalam rumah tangga negara(staatshuishouding).

Dalam bahasa Arab, ekonomi dinamakan al-mu'amal ah al- maddiyah, Yaitu aturanaturan tentang pergaulan dan Perhubungan manusia mengenai kebutuhan hidupnya. disebut juga al-iqtisha'ad, Yaitu peraturan soal-soal penghidupan manusia dengan hemat-hemat nya dan secermat cermatnya. secara istilah, pengertian ekonomi Islam dikemukakan dengan redaksi yang beragam dikalangan para pakar ekonomi Islam.

Menurut Mohammad Nejatullah Siddiqi ekonomi Islam adalah jawaban dari pemikir Muslim terhadap tantangan-tantangan ekonomi pada zamannya .Dalam upaya ini mereka dibantu oleh Alquran dan as-sunnah nabi akal pikiran dan pengalaman. M.abdul mannan mendefinisikan ekonomi Islam dengan ilmu pengetahuan sosial yang mempelajari masalahmasalah ekonomi rakyat diilhami dengan nilai-nilai Islam. definisi yang hampir sama dikemukakan oleh M.M. Metwally bahwa ekonomi Islam adalah ilmu yang mempelajari perilaku muslim (orang-orang yang beriman) dalam suatu masyarakat Islam yang mengikuti Alquran, hadis nabi, Ijma, dan qiyas. menurut Yusuf Al qardhawi, ekonomi Islam adalah ekonomi yang berdasarkan Ketuhanan. sistem ini bertitik tolak dari Allah, bertujuan akhir Kepada Allah, Dan menggunakan sarana yang tidak lepas dari syariat Allah.

Khurshid Ahmad Mendefinisikan ekonomi Islam dengan usaha sistematis untuk memahami masalah ekonomi Dan perilaku manusia dalam hubungannya kepada persoalan tersebut menurut perspektif Islam.syed nawab haider naqvi memahami ekonomi Islam dalam perspektif sosiologi yang mempelajari perilaku manusia dalam perekonomian di segala aspek kehidupan dengan corak yang Khas. bagi naqvi, ekonomi Islam lebih ditekankan sebagai sains yang bertugas menyibak permasalahan manusia dalam sebuah masyarakat muslim dengan pola dan corak hidup yang tipikal.

Adapun M. Umer Chapra mendefinisikan ekonomi Islam dengan cabang pengetahuan yang membantu merealisasikan kesejahteraan manusia melalui suatu alokasi dan distribusi sumber-sumber daya langka yang seirama dengan maqashid, tanpa mengekang kebebasan 
individu, menciptakan ketidakseimbangan makro ekonomi dan ekologi Yang berkepanjangan, atau melemahkan solidaritas keluarga dan sosial serta jaringan masyarakat.

Berdasarkan pengetian di atas maka penulis memberikan pengertian ilmu ekonomi islam adalah pengetahuan dan aplikasi dari anjuran dan aturan Syariah ah yang mencegah ketidak adilan dalam memperoleh sumber-sumber daya materiel sehingga tercipta kepuasan manusia dan dan memungkinkan mereka menjalankan perintah Allah dan mengikuti aturan masyarakat.

\section{2) Dasar Ekonomi Islam}

Ada tiga aspek yang sangat mendasar dalam ajaran Islam, yaitu aspek akidah, hukum dan akhlak. ketika seseorang memahami tentang ekonomi Islam secara keseluruhan, maka ia harus mengerti ekonomi Islam dalam aspek tersebut. ekonomi Islam dalam dimensi aqidah nya mencakup atas dua hal: 1) pemahaman tentang ekonomi Islam yang bersifat ekonomi ilahiyah, 2) Pemahaman tentang ekonomi Islam yang bersifat robbaniyah.

Segala pembahasan yang berkaitan dengan ekonomi Islam sebagai ekonomi ilahiyah, berpijak pada ajaran tawhid uluhiyyah. Ketika seseorang pesankan dan menyembah Allah Sebagai zat yang wajib disembah dan juga tidak kutukannya (al- An'am [16]: 102 dan adzDzariyat [51]: 56), Hari ini berimplikasi pada adanya niat yang tulus, bahwa segala pekerjaan yang dikerjakan oleh manusia adalah dalam rangka beribadah kepada Allah, sebagai satu bentuk penyembahan kepadanya. termaksuk Ketika seseorang melakukan kegiatan ekonomi dalam kesehariannya.

Adapun pembahasan tentang ekonomi Islam sebagai ekonomi rabbaniyah, berpijak pada ajaran tauhid rububiyah. tauhid rububiyah adalah mengesakan Allah melalui segala hal yang telah diciptakannya dengan selalu meyakini bahwa Allah merupakan pencipta alam semesta( az- Zumar [39: 62], Ketika seseorang menyembah Allah, dikarenakan kapasitas Allah sebagai pemberi Rezeki dan segala kenikmatan yang ada di dunia, maka ketika ia bersyahadat dan berikrar mengabdi kepada Allah, ia haruslah mampu memanfaatkan apa yang ada di dunia ini dengan sebaik-baiknya, sehingga bisa membawa kemaslahatan bagi masyarakat.

Selain aspek aqidah dan Syariah dalam ekonomi Islam. Satu aspek lagi yang menjadi nafas bagi tumbuh kembangnya ekonomi Islam, yaitu aspek moral yang selalu menjadi Spirit dalam setiap aktivitas yang terbangun di dalamnya. Ketika seseorang masuk ke dalam area ekonomi Islam, maka secara tidak langsung ia telah membuat kontrak pada dirinya agar senantiasa menjunjung tinggi moral yang merupakan tonggak perekonomian. Dan perlu 
diingat, bahwa profesionalitas tanpa adanya integritas yang baik akan melahirkan sistem dan praktik yang cacat dalam perekonomian. sehingga moral ataupun akhlak merupakan poin yang sangat penting dalam Ekonomi Islam.

Ada beberapa dasar hukum yang menjadi landasan pemikiran dan penentuan konsep dasar ekonomi syariah, antaralain:

a. Alquran merupakan dasar hukum utama konsep ekonomi syariah, karena Alqur'an merupakan ilmu pengetahuan yang berasal langsung dari Allah. Beberapa ayat dalam Alqur'an merujuk pada perintah kepada manusia untuk mengembangkan sistem ekonomi yang bersumber pada hukum Islam. Di antaranya terdapat pada Alqur'an surah Fussilat: 42, Az-Zumar: 27 dan AlHasyr: 22.

b. Hadis dan sunnah merupakan perkataan, perbuatan dan takrir dari Nabi Muhammad SAW. Kedua sumber ini dapat dijadikan dasar penetapan ekonomi syariah.

c. Ijtihad menurut bahasa adalah bersungguh-sungguh dalam mencurahkan pikiran. Sedangkan menurut istilah syara' ijtihad adalah mencurahkan seluruh kemmpuan dan pikiran dengan sungguh-sungguh dalam menetapkan hukum syariat dengan caracara tertentu. Ijtihad merupakan sumber hukum yang ketiga setelah Al-qur'an dan hadis, yang berfungsi untuk menetapkan suatu hukum apabila hukum tersebut tidak dibahas didalam AlQur'an dan hadis dengan syarat menggunakan akal sehat dan pertimbangan yang matang. orang yang melakukan ijtihad disebut dengan mujtahid. Sumber hukum hasil dari metodologi ijtihad adalah ijma', qiyas, maslahah mursalah, sad adz-dzariah, 'urf, istihsan, istishab dan lain-lain

\section{3) Tujuan ekonomi islam}

Tujuan ekonomi Islam adalah maslahah (kemaslahatan) bagi umat manusia. yaitu dengan mengusahakan segala aktivitas demi tercapainya hal-hal yang berakibat pada adanya kemaslahatan bagi manusia, atau dengan mengusahakan aktivitas yang secara langsung dapat merealisasikan kemaslahatan itu Sendiri. Aktivitas lainnya demi menggapai kemaslahatan adalah Dengan menghindarkan diri dari segala hal yang membawa mafsadah (kerusakan) bagi manusia. Menjaga kemaslahatan bisa dengan cara Min haytsu al- wujud Dengan cara mengusahakan segala bentuk aktivitas dalam ekonomi yang bisa membawa kemaslahatan. Dan an-nur Jagalan kemaslahatan Min haytsu al-adam Adalah dengan cara memerangi segala yang bisa menghambat jalannya kemaslahatan itu sendiri.

\section{4) Karakteristik Ekonomi Islam}

Karakteristik utama Islam adalah keteraturan dan keserasian.Satu-satunya ajaran di dunia yang memiliki sistem dan konsep penataan kehidupan yang paling lengkap adalah ajaran Islam. Bayangkan, mulai dari bangun tidur di pagi hari hingga tidur kembali di malam hari, dalam kehidupan seorang muslimada aturan dan tata cara yang harus dikerjakan. Mulai dari masalah akidah, ibadah, akhlak, keluarga, pendidikan, budaya, muamalah, dan segala aspek 
kehidupan manusia baik materiil atau non materiil.Kelengkapan aturan ini seiring dengan keserasian dengan karakteristik, sifat, dan tingkah laku manusia.

Ekonomi syari'ah dibangun atas empat karakteristik:

a. Dialektika nilai-nilai spritualisme dan materialisme. Sistem ekonomi kontemporer hanya konsen terhadap nilai yang dapat meningkatkan utilitysaja, hanya terfokus kepada nilai materializesaja, sedangkan ekonomi Syari'ah selalu menekankan kepada nilai-nilai kebersamaan dan kasih saying sesama indivindu dan masyarakat.

b. Kebebasan berekonomi dalam arti sistem ekonomi Islam tetap membenarkan kepemilikan individu dan kebebasan dalam bertransaksi sepanjang dalam cakupan Syari'ah.

c. Dualisme kepemilikan, pada hakikatnya pemilik alam semesta beserta isinya hanya milik Allah semata. Manusia hanya sebagai wakil Allah dalam memakmurkan dan mensejahterakan bumi.

d. Menjaga kemaslahatan individu dan masyarakat.

\section{B. Transaksi Dalam Muamalah Islam}

\section{1) Pengertian Transaksi}

Transaksi, berasal dari bahasa Inggris "transaction”. Dalam Bahasa Arabnya sering disebut sebagai al-Mu'amalat. Dengan demikian transaksi merupakan kata lain dari alMu'amalat. Dalam konteks ilmu fiqh, ilmu fiqh yang mempelajari tentang al-Mu'amalat disebut fiqh al-Mu'amalat. Fiqh al-Mu'amalat, dalam salah satu pengertiannya, mencakup bidang yang sangat luas yaitu mencakup hukum-hukum tentang kontrak, sanksi, kejahatan, jaminan, dan hukum-hukum lain yang bertujuan mengatur hubungan-hubungan sesama manusia, baik perorangan maupun kelompok.

Pengertian fiqh al-Mu'amalat yang lebih sempit, dikemukakan oleh Mustafa Ahmad alZarqa' yaitu hukum-hukum tentang perbuatan dan hubungan-hubungan sesama manusia mengenai harta kekayaan, hak-hak dan penyelesaian sengketa tentang hal-hal tersebut. Pengertian yang lebih teknis dikemukakan Mohammad Ma'sum Billah, yaitu suatu bentuk kesepakatan menguntungkan yang terjadi antara manusia untuk memenuhi segala kebutuhan hidup sehari-hari, khususnya dalam urusan yang berkaitan dengan perdagangan dan perniagaan.

Dari berbagai keterangan tersebut di atas dapat disimpulkan bahwa fiqh al-Mu'amalat adalah suatu bidang fiqh yang memfokuskan pada hukum-hukum tentang perbuatan dan hubungan-hubungan sesame manusia mengenai harta kekayaan, hak, dan penyelesaian sengketa tentang hal-hal tersebut dalam rangka memenuhi kebutuhan seharihari mereka dengan berpandukan Syari'ah

\section{2) Sumber Hukum Dalam Trasaksi Islam}

Sumber hukum transaksi dalam Islam adalah al-Qur'an, al-Sunnah, ijtihad (termasuk di dalamnya menggunakan instrumen ijma, qiyas, al-maslahah al-mursalah, 'urf, istishab, sad al- 
dhari'ah, dan lain-lain yang diakui sebagai instrumen ijtihad). Di samping itu terdapat fiqh legal maxim (kaidah fiqhiyyah) yang merupakan suatu prinsip umumyang bisa dijadikan panduan umum dalam pembangunan hukum Islam terutama apabila terdapat masalah-masalah baru yang memerlukan keputusan hukum secara cepat. Berikut ini, akan dijelaskan beberapa panduan yang digariskan Alquran dan al-Sunnah serta kaidah yang diformulasikan para ulama fiqh dalam bentuk kaidah fiqhiyyah mengenai prinsip-prinsip pokok transaksi dalam Islam.

a. Al-qur'an

Al-Quran menggariskan bahwa sebuah transaksi hanya sah apabila masing-masing pihak yang terlibat dalam transaksi memenuhi kewajiban yang berkaitan dengan konsekuensi sebuah transaksi. Misalnya dalam transaksi yang berbentuk akad jual beli, seorang pembeli harus membayar sejumlah harga yang disepakati, sementara penjual harus menyerahkan barang yang dijualnya kepada pembeli.

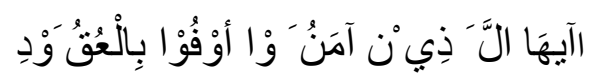

"Wahai orang-orang yang beriman penuhilah akad-akadmu". (Terjemahan Q.S. alMa'idah (5):1)

Seseorang yang berjanji, harus memenuhi janjinya. Allah SWT berfirman:

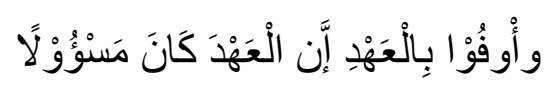

"Penuhilah janji, sesungguhnya janji itu akan dimintai pertanggungjawaban".

(Terjemahan Q.S. al-Isra' (17): 34).

Al-Quran juga menyebutkan bahwa semua transaksi mestilah dilakukan dalam rangka kerjasama yang saling menguntungkan, sebagaimana disebutkan:

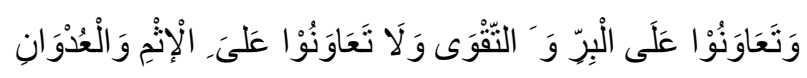

"Bertolong menolonglah kamu dalam kebaikan dan taqwa, dan janganlah bertolong menolong dalam dosa dan permusuhan". (Terjemahan Q.S. al-Ma'idah (5): 2)

b. As-Sunnah

Petunjuk yang sangat gamblang disampaikan Rasulullah SAW tentang apa saja yang dibolehkan dan apa yang dilarang melalui hadis beliau yang artinya:

Dari Nu'man bin Basyir, ia berkata: Rasulullah SAW bersabda: "Segala sesuatu yang halal dan haram itu sudah jelas, di antara keduanya terdapat hal-hal yang samar dan tidak diketahui oleh kebanyakan orang. Barang siapa yang meninggalkan apa-apa yang menyerupai (mendekati) dosa, maka ia berarti telah meninggalkan yang haram. Tetapi barangsiapa mengikuti hal-hal yang meragukan yang cenderung ke dosa, maka ia sebenarnya telah terjerumus pada yang haram. Semua dosa adalah lading (larangan) Allah, barangsiapa yang melangkahkan kakinya di seputar ladang (larangan) tersebut, dikhawatirkan ia akan duduk diladang itu. (H.R. Bukhari). 


\section{3) Hubungan antara Transaksi (Muamalah), Syariah, Fiqh, Iman, Ibadah, dan Akhlaq}

Sebagaimana dijelaskan di atas, transaksi merupakan perbuatan dan hubunganhubungan sesama manusia mengenai harta kekayaan, hak, dan penyelesaian sengketa tentang hal-hal tersebut dalam rangka memenuhi kebutuhan sehari-hari mereka dengan berpandukan Syariah. Pengertian ini jelas sekali menunjukkan hubungan antara transaksi dengan Syariah. Syariah menjadi guideline bagi semua aktivitas transaksi. Aktivitas transaksi yang tidak mengikuti ketentuan Syariah berarti dilarang (diharamkan).

Syariah merupakan ketentuan-ketentuan Allah yang ditujukan untuk menjadi panduan bagi umat manusia dalam menjalani kehidupan. Syariah adalah satu-satunya way of life yang harus dipercayai oleh seorang mukmin yang dapat mengantarkannya mencapai kebahagiaan hidup di dunia dan akhirat. Allah-lah satu-satunya pihak yang berkuasa untuk menentukan ketentuan dan jalan yang mesti ditaati oleh umat manusia, karena Dia-lah Pencipta dan Pemelihara alam semesta. Inilah reason, kenapa semua aktivitas transaksi harus mengikuti guideline yang ditetapkan Syariah.

Fiqh berarti faham, baik secara mendalam atau dangkal. Dalam pengertian yang spesifik, ia berarti memahami hukum-hukum amalisyarak berdasarkan dalil-dalilnya yang terperinci. Dengan kata lain, pemahaman terhadap Syariah itu dinamakan fiqh. Ini berarti fiqh merupakan produk pemikiran manusia (hasil ijtihad) yang senantiasa dinamis mengikuti perkembangan zaman. Nilai kebenaran yang dihasilkan oleh hasil ijtihad bersifat relatif, liberal, terbuka untuk diuji dan dikaji ulang serta terbuka untuk dikritik karena kefahaman manusia senantiasa berkembang mengikuti perkembangan ilmu, nilainilai intelektual, dan juga situasi kontemporer dan realitas setempat yang melingkupi suatu kefahaman. Syariah bersifat muqaddas, abadi dan kebenarannya mutlak. Dengan demikian, Syariah dan fiqh mempunyai hubungan yang sangat erat, karena sesungguhnya fiqh tetap berpijak pada Syariah. Adanya fiqh merupakan suatu keharusan dalam rangka mengamalkan Syariah.

Sedangkan fiqh muamalah adalah peraturan Islam yang berkaitan dengan hukumhukum perniagaan, dan menjadi frame work yangsah untuk ekonomi Islam. Hubungan antara fiqh muamalah dan ekonomi Islam adalah seumpama kajian tata bahasa dengan kemahiran penggunaan bahasa. Kegiatan ekonomi Islam tidak bisa dipisahkan dari fiqh muamalah, bahkan kegiatan itu hendaklah dikawal dan dipandu oleh fiqh muamalah.

Sedangkan iman, berarti percaya. Beriman berarti mempercayaiAllah SWT sebagai pencipta dan pemelihara alam semesta, percayapada malaikat, rasul, kitab-kitab, hari akhir, dan qadla qadar. Orang yang mempercayai rukun iman tersebut disebut mukmin (orang yang beriman). Orang yang beriman dalam menjalani kehidupan haruslah berpandu kepada Syariah, 
karena Syariah adalah guideline dari Allah SWT untuk orang beriman. Dengan demikian, iman dan Syariah merupakan dua elemen yang saling melengkapi (komplementer) dan saling mendukung dalam membentuk pribadi muslim sejati.

Ibadah berarti pengabdian atau penghambaan diri kepada Allah. Ibadah dalam pengertian yang mudah ditangkap oleh masyarakat muslim seringkali mengambil pengertian yang lebih khusus yakni pengabdian kepada Tuhan dalam bentuknya yang paling pribadi yakni ritus-ritus seperti shalat, puasa, zakat, haji, berzikir dan sejenisnya. Pemahaman ini tentu saja mereduksi secara besar-besaran makna ibadah dalam pengertiannya yang genuine. Ketika Allah menyatakan bahwa "Jin dan manusia diciptakan untuk beribadah kepada-Nya" (Terjemahan Q.S. al-Dhariyat (51): 56), dan "Semua utusan Tuhan diperintahkan untuk mengajak manusia beribadah kepada Allah" (Q.S. al-Bayyinah (98): 5), maka makna ibadah tersebut tidak mungkin hanya berarti untuk shalat, puasa, zakat, haji, berzikir dan sejenisnya.

\section{KESIMPULAN}

Berdasarkan penjelasan tersebut di atas maka kami penulis memberikan kesimpulan sebagai berikut:

1. Tiga aspek yang sangat mendasar dalam ajaran Islam, yaitu aspek akidah, hukum dan akhlak.

2. Ekonomi Islam dalam dimensi aqidah nya mencakup atas dua hal: 1) pemahaman tentang ekonomi Islam yang bersifat ekonomi ilahiyah ;2) Pemahaman tentang ekonomi Islam yang bersifat robbaniyah.

3. Dasar hukum yang menjadi landasan pemikiran dan penentuan konsep dasar ekonomi syariah, antaralain: a) Al-Qur'an, b) Hadist dan As-Sunnah, c) Ijtihad.

4. Tujuan ekonomi Islam adalah maslahah bagi umat manusia. yaitu dengan mengusahakan segala aktivitas demi tercapainya hal-hal yang berakibat pada adanya kemaslahatan bagi manusia, atau dengan mengusahakan aktivitas yang secara langsung dapat merealisasikan kemaslahatan itu sendiri.

5. Transaksi merupakan kata lain dari al-Mu'amalat. Dalam konteks ilmu fiqh, ilmu fiqh yang mempelajari tentang al-Mu'amalat disebut fiqh al-Mu'amalat. Fiqh al-Mu'amalat, dalam salah satu pengertiannya, mencakup bidang yang sangat luas yaitu mencakup hukum-hukum tentang kontrak, sanksi, kejahatan, jaminan, dan hukum-hukum lain yang bertujuan mengatur hubungan-hubungan sesama manusia, baik perorangan maupun kelompok. 


\section{DAFTAR PUSTAKA}

Arsi, A., Fail, W. O. N., \& Arsyam, M. (2021, January 16). Membangun Keluarga Yang Islami. https://doi.org/10.31219/osf.io/43ygj

Janna, NM, \& Arsyam, M. (2021). Makanan Dan Minuman Dalam Islam.

Ahmad, H., \& Arsyam, M. (2020). ETIKA PERDAGANGAN DALAM ISLAM.

Arsyam, M. (2020). Manajemen pendidikan islam.

N., Fajrin, M. F., \& Arsyam, M. (2021, January 19). Ibadah Sebagai Aspek Ritual Ummat Islam. https://doi.org/10.31219/osf.io/frs65

Usman, H. A., Arsyam, M., \& Yusuf, M. (2021, January 17). ETIKA PERDAGANGAN DALAM ISLAM. Retrieved from osf.io/q6rbz

Rifqi, N., Fajrin, M. F., \& Arsyam, M. (2021). Ibadah Sebagai Aspek Ritual Ummat Islam.

Aisyah, B. N. (2019). Etos Kerja Dalam Islam. Amal: Jurnal Ekonomi Syariah, 1(01).

Wijayanti, R. (2018). Membangun Entrepreneurship Islami dalam Perspektif Hadits. Cakrawala: Jurnal Studi Islam, 13(1), 35-50.

Shobir, L. M. (2017). Tasawuf Enterpreneurship: Membangun Etika Kewirausahaan Berbasis Prophetic Intelligence. IAIN Tulungagung Research Collections, 3(2), 417-432.

Mardani, D. A. (2019). Spritual Entrepreneurship Dalam Pemberdayaan Ekonomi Umat. Al Amwal (Hukum Ekonomi Syariah), 2(1), 37-44.

Zakirah, Z., Arsyam, M., HERIANTO, H., \& Umar, K. (2020, December 20). PENDIDIKAN DASAR (KUTTAB) MASA DAULAH ABBASIYAH (132-232 $\mathrm{H} \quad / \quad 750-847$ M). https://doi.org/10.31219/osf.io/7t8bs

Depertemen Agama RI, Al-Qur'an dan Terjemahnya, (Bandung: PT. Syaamil Cipta Media)

Arsyam, M., \& Kusnadi Umar, Z. Z. MANUSIA SEBAGAI PENDIDIK PERPEKTIF ISLAM DAN BARAT.

Sapada, A. O., \& Arsyam, M. (2020). Ilmu Pengetahuan dan Teknologi Menurut Pandangan Islam.

Arsyam, M., \& Sainuddin, I. H. Meraih Surga dengan Sabar dan Syukur.

Zakirah, Z., Jumliadi, J., Arsyam, M., Herianto, H., Rusli, M., \& Alwi, A. M. Implementation of The Islamic Local Regulations in Bulukumba Regency.

Jumliadi, J., Zakirah, Z., Arsyam, M., Alwi, A. M. S., \& Fadhil, M. PEMBELAJARAN DIRUMAH DALAM LINGKUNGAN KELUARGA DI TENGAH PANDEMI COVID 19. 